\title{
Splenic Malignant Lesions in Lymphoma and Solid Tumors, A Comparative Study of Imaging Techniques
}

\author{
Emel OZEN ${ }^{1}$, Mehmet OZEN $^{2}$, Nazan CILEDAG ${ }^{1}$, Feyza KABAR ${ }^{1}$, \\ Mehmet GUNDUZ², Bilgin K. ARIBAS ${ }^{1}$ \\ ${ }^{1}$ Ankara Oncology Research and Education Hospital, Department of Radiology \\ ${ }^{2}$ Ankara University School of Medicine, Department of Hematology, Ankara, TURKEY
}

\begin{abstract}
Splenic involvement guide treatment and affect prognosis in lymphoma and solid tumors. The most common used imaging techniques in detecting splenic involvement are Ultrasound (US) and Computed Tomography (CT). In this study, our aims were to evaluate the imaging findings regarding the spleen, compare splenic lesions according to the diagnosis and evaluate correlations between US and CT according to splenomegaly and lesions. Between May 2008 and April 2011 we identified 72 patients with splenic lesions or splenomegaly on CT or US. However, we exclude 27 patients from the study because of study protocol. Therefore, we enrolled 45 patients with a proven malignancy who had splenic lesions detected with CT. Seventeen patients had a diagnosis of lymphoma, and 28 patients had non-hematological malignancies. The characteristic features of the splenic lesions, detected on CT in patients with a proven malignancy, varied according to the cancer type. Multiple splenic lesions and splenomegaly in lymphoma patients and only solitary lesions in solid tumors were seen on CT ( $p<0.001)$. Lymphoma patients usually had a solid splenic lesion with splenomegaly on US, but no lesion in solid tumors were seen on US ( $p<0.05)$. The US and CT correlation ratio was inferior for solid tumors.US may miss splenic solid tumor metastases. CT is useful for distinguishing splenic lymphoma involvement from solid tumor metastases. CT seems superior to US in detecting splenic solid tumor metastases.
\end{abstract}

Keywords: Spleen, Ultrasound, Computed Tomography, Lymphoma, Solid Malignancies

ÖZET

Lenfoma ve Solid Tümörlerde Dalağın Malign Lezyonları, Görüntüleme Teknikleri Kıyaslama Çalışması

Lenfoma ve solid tümörlerde dalak tutulumu prognozu etkilemekte ve tedaviye klavuzluk etmektedir. Dalak tutulumunun tanımlanmasında en sık kullanılan görüntüleme teknikleri Ultrason (US) ve Bilgisayarlı Tomografi (BT)'dir. Bu çalışmada dalağın görüntüleme bulgularını değerlendirmeyi, tanıya göre dalak lezyonlarını kıyaslamayı ve splenomegali ve lezyonlara göre US ve BT arasındaki korelasyonu değerlendirmeyi amaçladık. Mayıs 2008 ve Nisan 2011 arasında BT veya US'de splenomegali veya dalak lezyonları olan 72 hasta tanımladık. Ancak, 27 hastayı çalışma protokolü nedeniyle çalışmadan çıkarttık. Sonuçta kanıtlanmış bir malignensisi olan ve BT ile dalakta lezyonu saptanmış 45 hastayı çalışmaya aldık. On yedi hastanın tanısı lenfoma, 28 hastanın tanısı ise hematolojik olmayan malignensi idi. Kanıtlanmış bir malignensisi olan hastalarda BT'de gözlenen dalak lezyonlarının karakteristik özellikleri kanser tipine göre farklllkk gösterdi. BT'de lenfoma hastalarında dalakta çok sayıda lezyonla birlikte splenomegali görülürken, solid tümörlerde yalnızca tek lezyon görüldü ( $p<0.001)$. US'de lenfoma hastalarında genellikle bir solid lezyona eşlik eden splenomegali varken, solid tümörlerde US'de lezyon gözlenmedi ( $p<0.05)$. US ve BT'nin korelasyon oranı solid tümörlerde düşüktü. US solid tümör metastazını gözden kaçırabilir. BT lenfomanın dalak tutulumunu solid tümörlerin dalak metastazından ayırmada faydalıdır. BT dalaktaki solid tümör metastazlarını tanımlamada US'ye üstün görünmektedir.

Anahtar Kelimeler: Dalak, Ultrason, Bilgisayarlı Tomografi, Lenfoma, Solid Malignensiler 


\section{INTRODUCTION}

Although many imaging techniques can be used to evaluate malignant splenic lesions, computed tomography (CT) and ultrasound (US) are usually performed. Splenic involvement guide treatment and affect the prognosis. ${ }^{1}$ Most clinicians make treatment decisions based on CT and US findings. Therefore, CT and US findings provide the most important information for making treatment decision.

Although many diseases may increase the spleen size, the spleen size is extremely important for diagnosing and determining the prognosis of hematological disorders. ${ }^{2}$ In lymphoma, splenomegaly $(>12 \mathrm{~cm}$ spleen size) may be unique imaging finding on US. ${ }^{2}$ Lesion or lesions on US might also be detected in lymphoma and may be solitary or multiple on CT. ${ }^{1,3}$

Although CT is necessary in most patients who require abdominal imaging for tumor staging, sometimes only US is used to evaluate patients with lymphoma or solid malignancy. ${ }^{1,3-5}$ In this retrospective study, our aims were to evaluate the US and CT findings, to compare malignant splenic lesions according to the diagnosis and to evaluate correlations in the same patients between US and $\mathrm{CT}$ according to splenomegaly or malignant splenic lesions. To the best of our knowledge, there is no study comparing the US and CT findings of malignant splenic lesions in lymphoma and solid tumor patients.

\section{PATIENTS AND METHODS}

In our radiology department, we retrospectively evaluated all patients between May 2008 and April 2011. The patients' data and imaging findings were collected from hospital files and computer-based data. We identified 72 patients with splenic lesions or splenomegaly on CT or US. However, 27 patients were excluded from the study because of several reasons (Figure 1). Therefore, we enrolled 45 patients who had a lesion on CT and pathologically confirmed malignancy.

Nineteen patients did not undergo US, but 26 of the 45 patients underwent US. We also separately evaluated these 26 US patients' findings in the study.
The radiologists evaluating US and CT in these 26 patients were different. Radiologists evaluating US only knew the patients' diagnoses, but they did not know the CT findings. To achieve this, US was performed before $\mathrm{CT}$ in all 26 patients.

On abdominal CT, hypodense lesions in the spleen are usually detected. ${ }^{6}$ When not otherwise determined, hypodense irregular contrasting lesions should be accepted as metastases. ${ }^{6}$ Therefore, in our study, we considered metastases when a patient had proven malignancy and lesions in the spleen on CT. However, when evaluating the patients' images, radiologists were free to select imaging assessment criteria on US or CT without guidance.

We used a General Electric 4 detector CT (Hispeed QXi, Milwaukee, USA) and Toshiba Nemio or Siemens Sonoline G40 US machines.

Our study has been approved by local ethic committee.

\section{Statistics}

We used Microsoft Excel 2003 and SPSS 15.0 to analyze the patients' data. Ordinal variables were calculated as the mean \pm standard deviation. The Chi-square test is used for statistical analysis. We considered a $p$ value $<0.05$ as significant.

\section{RESULTS}

We enrolled 45 patients with a mean age of $57.2 \pm 18.2$. Seventeen patients were female, and 28 patients were male. When classified according to diagnosis, seventeen (37.8\%) patients had lymphoma (five Hodgkin's and twelve non-Hodgkin's), six (13.3\%) patients had breast cancer, four $(8.8 \%)$ patients had colorectal cancer, four $(8.8 \%)$ patients had gastric cancer, three $(6.7 \%)$ patients had ovarian cancer, and two (4.4\%) patients had lung cancer. Additionally, one (2.2\%) patient each had a diagnosis of malignant lower extremity tumor, malignant melanoma, prostate cancer, larynx cancer, endometrial cancer, hepatocellular carcinoma, malignant epithelial tumor, bladder cancer or pancreatic cancer.

On CT, twelve patients had splenomegaly and lesion(s): eleven were lymphoma, and one was 


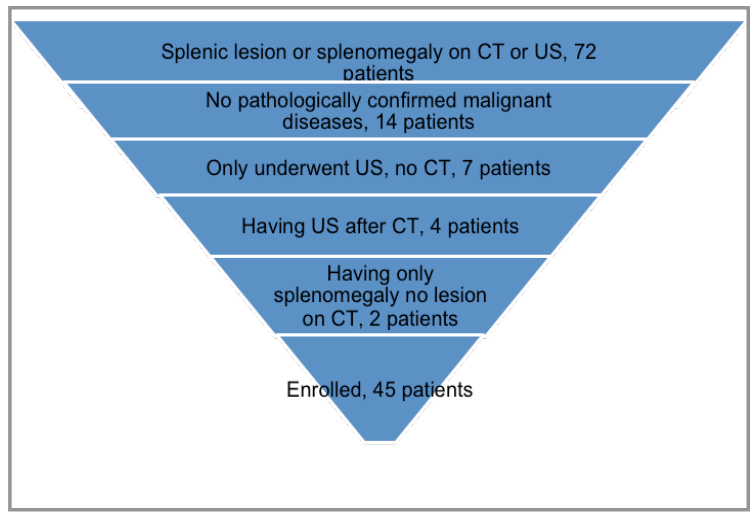

Figure 1. Patient enrollment

hepatocellular carcinoma. Thirty-three patients only had a lesion on CT: six were lymphoma, and 27 were solid tumors (Figure 2 and Table 1). Lymphoma was associated with splenomegaly plus lesion(s) and solid tumors were associated with lesion alone $(\mathrm{p}<0.001)$.



Figure 2. Lesion type and splenomegaly on CT

On CT, 44 patients had a hypodense lesion, but a lymphoma patient had a hyperdense lesion. Additionally, 25 patients had solitary lesions, and 20 patients had multiple lesions on CT (Figure 2 and Table 1). Lymphoma metastases were usually multiple, but other malignancy metastases were solitary $(\mathrm{p}<0.001)$.

Table 1. Splenomegaly and lesion on CT and US according to disease

\begin{tabular}{|c|c|c|c|}
\hline Findings & Solid n (\%) & Lymphoma n (\%) & $\mathbf{p}$ \\
\hline \multicolumn{4}{|l|}{ CT Findings } \\
\hline \multicolumn{3}{|c|}{ Lesion with/without Splenomegaly } & $<0.001$ \\
\hline Splenomegaly and lesion & $1(3.6 \%)$ & $11(64.7 \%)$ & \\
\hline Only lesion & 27 (96.4\%) & $6(35.3 \%)$ & \\
\hline \multicolumn{3}{|l|}{ Number of Lesions } & $<0.001$ \\
\hline Solitary lesion & $21(75 \%)$ & $4(23.5 \%)$ & \\
\hline Multiple lesions & $7(25 \%)$ & $13(76.5 \%)$ & \\
\hline \multicolumn{4}{|l|}{ US Findings } \\
\hline \multicolumn{3}{|l|}{ US findings } & $<0.01$ \\
\hline Normal US & 9 (60\%) & $2(18.2 \%)$ & \\
\hline Splenomegaly or lesion & $6(40 \%)$ & 9 (82.8\%) & \\
\hline \multicolumn{3}{|l|}{ Lesion } & $<0.01$ \\
\hline No & $10(66.7 \%)$ & 2 (18.2\%) & \\
\hline Yes & 5 (33.3\%) & 9 (82.8\%) & \\
\hline \multicolumn{3}{|l|}{ Lesion type } & $<0.05$ \\
\hline Solid & $3(60 \%)$ & $7(77.8 \%)$ & \\
\hline Solid-cystic/ Cystic & $2(40 \%)$ & 2 (22.2\%) & \\
\hline
\end{tabular}




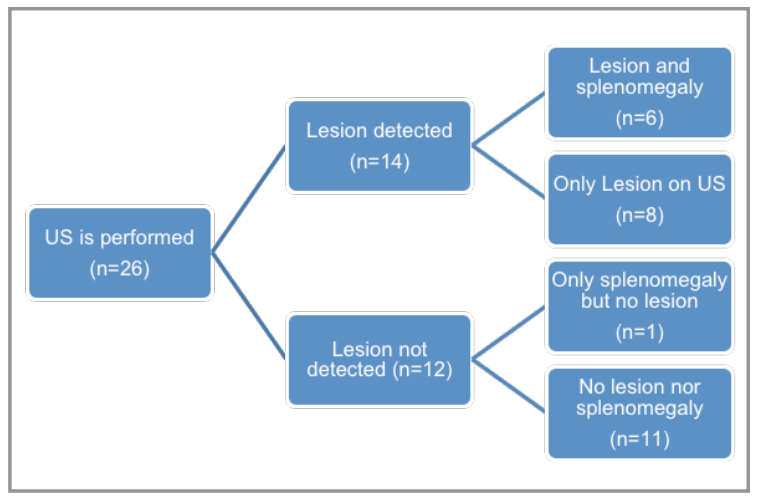

Figure 3. Lesion and splenomegaly on US

All of these 45 patients had a lesion or lesions on CT. In these 45 patients, 26 patients also underwent US. Lesions or splenomegaly were detected in fifteen patients on US. However, eleven patients had normal US findings (neither lesions nor splenomegaly) (Figure 3 and Table 1). Normal US findings were more frequent in solid malignancy patients $(p<0.01)$ and more solid lesions were seen in lymphoma $(\mathrm{p}<0.05)$ (Table 1).

We also evaluated CT and US correlations in these 26 patients who underwent US according to splenomegaly and lesion. Only eleven patients (five patients with only lesion on US and CT and six with a lesion and splenomegaly on US and CT) had similar findings on US and CT. However, in fifteen patients neither splenomegaly nor lesions were seen on US (Table 2). The overall correlation ratio for US and CT was $42.3 \%$. The US and CT correlation ratio for lymphoma was $63.6 \%$ and for solid tumors was $26.7 \%$; lymphoma had a tendency for a high US and CT correlation $(\mathrm{p}=0.06)$.

We also separately evaluated patients according to their diagnoses. The patients' imaging findings according to diagnosis are shown in Table 3. No differences were seen between lymphoma and solid tumors according to the presence of other organ involvement.

\section{DISCUSSION}

In our study most of patients had lymphoma and splenic solid tumor metastases mostly originated from breast cancer, colorectal cancer, gastric cancer, ovarian cancer and lung cancer. Our findings are similar to literature. The most common metastatic tumor of spleen is lymphoma involvement. ${ }^{6,7}$ In non-hematological malignant patients, splenic metastases mostly originate from breast, ovarian, malignant melanoma, pancreas, lung, colorectal and gastric cancer. ${ }^{1,8,9}$ Metser et al compared 20 splenic solid tumor metastases with using PET and conventional imaging techniques. In this study, patients mostly had lung, colorectal and ovarian cancer. ${ }^{10}$ In other studies, splenic metastases are mostly associated with choriocarcinoma, malignant melanoma and lung, breast, gastric, pancreas and ovarian cancer. ${ }^{6,8,11-14}$

\begin{tabular}{|c|c|c|c|c|}
\hline \multirow[t]{2}{*}{ US findings } & \multirow[b]{2}{*}{ Normal } & \multicolumn{3}{|c|}{ CT findings } \\
\hline & & $\begin{array}{l}\text { Only } \\
\text { Splenomegaly }\end{array}$ & $\begin{array}{l}\text { Splenomegaly } \\
\text { and lesion }\end{array}$ & Only lesion \\
\hline Normal & $0(\%)$ & $0(\%)$ & $1(11.1 \%)$ & $11(64.7 \%)$ \\
\hline Only Splenomegaly & $0(\%)$ & $0(\%)$ & $1(11.1 \%)$ & $1(5.9 \%)$ \\
\hline Splenomegaly+lesion & $0(\%)$ & $0(\%)$ & $6(66.7 \%)^{\star \star}$ & $0(0 \%)$ \\
\hline Only lesion & $0(\%)$ & $0(\%)$ & $1(11.1 \%)$ & $5(29.4 \%)^{\star \star}$ \\
\hline 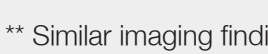 & 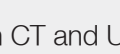 & & & \\
\hline
\end{tabular}




\begin{tabular}{|c|c|c|c|c|c|}
\hline Disease & $\begin{array}{l}\text { Solitary } \\
\text { Lesion }\end{array}$ & Multiple lesion & $\begin{array}{l}\text { Lymph node } \\
\text { metastases }\end{array}$ & $\begin{array}{l}\text { Other } \\
\text { metastases }\end{array}$ & Total \\
\hline Breast Cancer & 5 & 1 & 2 & 4 & 12 \\
\hline Colorectal Cancer & 4 & 0 & 0 & 3 & 7 \\
\hline Gastric Cancer & 1 & 3 & 2 & 2 & 8 \\
\hline Over Cancer & 1 & 2 & 2 & 3 & 8 \\
\hline Lung Cancer & 2 & 0 & 2 & 2 & 6 \\
\hline Total & 13 & 6 & 8 & 14 & 41 \\
\hline
\end{tabular}

In lymphoma, lesions are usually multiple and smaller than $1 \mathrm{~cm}$, but large, solitary lesion and splenomegaly may be seen on CT., ${ }^{1,6,7,15-19}$ In lymphoma, solid lesions may also be seen in the spleen on US. ${ }^{20}$ In our study, more solid lesions with splenomegaly on US and multiple hypodense lesions with splenomegaly on CT were seen in lymphoma patients. However, we did not detect splenomegaly on CT or US in some lymphoma cases. When looking at solid tumors, US detected neither lesions nor splenomegaly, but on CT, all cases had lesion and nearly all lesions were hypodense. We also detected more solitary lesions on CT in solid malignancies compared to lymphoma. This is a new finding because solitary metastases are poorly defined in the literature. Therefore, if a patient has lymphoma and a solid malignancy, CT and US findings may be useful for determining the metastasis origin and the characteristics of splenic malignant lesions may guide diagnosis and treatment.

A study showed that PET CT is superior to conventional $\mathrm{CT}$ in determining the splenic involvement in lymphoma. ${ }^{18}$ Other studies detected that the sensitivity of CT was between $37-91 \%$ and specificity is $96 \%$ and the sensitivity of US was $54-63 \%$ and the specificity was $99-100 \%$ in detecting splenic involvement of lymphoma. ${ }^{21-23}$ However, to our knowledge there is no study showing sensitivity and specificity data of CT and US in solid malignancies. In some of our patients with solid malignancies, lesions were detected on CT but not on
US. The time period for performing US and CT was close. Therefore, we cannot explain this situation with the subsequent lesion development. In some patients having splenic solid tumor metastases, CT shows lesions, while US does not. This explains the superior effect of CT to US in the sensitivity of detecting solid splenic tumor metastases. The correlation rates of US and CT were low in solid tumors and US was not a good option in making diagnosis. In solid tumors, CT may be more sensitive imaging option for detecting splenic metastases. In our study, we only examined patients having lesion on $\mathrm{CT}$, and we did not compare patients with using PET CT. This is a limitation of our study. However, we can speculate that US seems an acceptable alternative for detecting lymphoma patients' lesions compared to solid tumors, but it is not superior to CT.

Splenic involvement are mostly seen in terminal

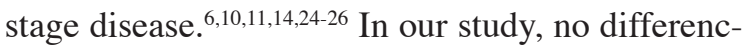
es were seen between lymphoma and solid tumors according to the presence of other organ involvement. In other words, when we detected a splenic tumor, there were no differences between lymphoma and solid tumors regarding the presence of other organ involvement. Therefore, we are not able to differentiate lymphoma and solid tumors according to existence of other organ involvements.

Our study had several limitations, including its retrospective nature, small sample size and single center design. Although, the patients had a patho- 
logically proven malignancy from the tumor origin, we are not certain if the lesions are associated with malignant metastases because splenic lesions were not evaluated by pathology.

In conclusion, we showed that the most common malignant disease causing splenic involvement was lymphoma. The characteristic features of splenic tumor involvements originated from lymphoma and solid malignancies were different. In lymphoma splenic involvement were seen as solid lesions on US and hypodense multiple lesions on CT. In the other solid tumors, US cannot identify metastases. However, CT can detect hypodense and solitary lesions in solid tumors. In solid tumors, choosing $\mathrm{CT}$ as the imaging modality for the spleen may be useful. Additionally, if a patient has lymphoma and a solid malignancy, CT findings can be useful for determining the origin of tumor.

\section{REFERENCES}

1. Ferrell AS, Lursen KP, Koehler RE. Spleen. In : Canon CL (Ed). Speciality Board Review Radiology, 1st Edition, New York; Mc Graw- Hill 2009; 398-404.

2. Hoffbrand AV, Moss PAH. The Spleen. In Essential Haematology. Table 10.1. http://www.essentialhaematology6.com/ tables/chapter10.pdf (Accessed 10 January 2012)

3. Özdikici M. Çocuklarda normal karaciger, dalak ve böbrek boyutlarPnPn ultrasonografi ile ölçümleri ve bunlarPn cinsiyet, yas, boy ve agirlikla olan iliskileri. Atatürk University Faculty of Medicine, Institute of Health Science, Anatomia Department Master Tesis, Erzurum, 2006.

4. Matacia-Murphy GM. Splenomegaly. http://emedicine.medscape.com/article/206208-overview (Accessed 10 January 2012).

5. Rolfes RJ, Ros PR. The spleen: an integrated imaging approach. Crit Rev Diagn Imaging 30: 41-83, 1990.

6. Rabushka LS, Kawashima A, Fishman EK. Imaging of the spleen: CT with supplemental MR examination. Radiographics 14: 307-332, 1994.

7. Dias AR, Pinto RA, Ravanini JN, et al. Isolated splenic metastasis from lung squamous cell carcinoma. World J Surg Oncol 10:24, 2012.
8. 8. Botrugno I, Jemos V, Cobianchi L, et al. A metachronous splenic metastases from esophageal cancer: a case report. World J Surg Oncol 9: 105, 2011

9. Cavanna L, Lazzaro A, Vallisa D, et al. Role of image-guided fine-needle aspiration biopsy in the management of patients with splenic metastasis. World J Surg Oncol 2;5: 13, 2007.

10. Karlo CA, Stolzmann P, Do RK, Alkadhi H. Computed tomography of the spleen: how to interpret the hypodense lesion. Insights Imaging 4: 65-76, 2013.

11. Taylor AJ, Dodds WJ, Erickson SJ, Stewart ET. CT of acquired abnormalities of the spleen. AJR 157: 1213-1219, 1991.

12. Kadin ME, Glaststein EJ, Dorfman RE. Clinicopathologic studies in 117 untreated patients subject to laparotomy for the staging of Hodgkin's disease. Cancer 27: 1277-1294, 1977.

13. Brox A, Shustik C. Non-Hodgkin's lymphoma of the spleen. Leuk Lymphoma 11: 165-171, 1993.

14. Castellino RA, Marglin S, Blank N. Hodgkin's disease, the non-Hodgkin's lymphomas and the leukemias in the retroperitoneum. Semin Roentgenol 15: 288-301, 1980.

15. Rini JN, Leonidas JC, Tomas MB, Palestro CJ. 18F-FDG PET versus $\mathrm{CT}$ for evaluating the spleen during initial staging of lymphoma. J Nucl Med 44: 1072-1074, 2003.

16. Kostakoglu L, Leonard JP, Kuji I, et al. Comparison of fluorine-18 fluorodeoxyglucose positron emission tomography and Ga-67 scintigraphy in evaluation of lymphoma. Cancer 94: 879-888, 2002.

17. Warshauer DM, Hall HL. Solitary splenic lesions. Semin Ultrasound CT MR 27: 370-388, 2006.

18. Gatenby PA, Mudan SS, Wotherspoon AC. Splenectomy for non-haematological metastatic malignant disease. Langenbecks Arch Surg 396: 625-638, 2011.

19. Compérat E, Bardier-Dupas A, Camparo P, et al. Splenic metastases: clinicopathologic presentation, differential diagnosis, and pathogenesis. Arch Pathol Lab Med 131: 965-969, 2007.

20. Metser U, Miller E, Kessler A, et al. Solid splenic masses: evaluation with 18F-FDG PET/CT. J Nucl Med 46: 52-59, 2005.

21. Berge T. Splenic metastases: frequencies and patterns. Acta Pathol Microbiol Scand 82: 499-506, 1974.

22. Morgenstern L, Rosenberg J, Geller SA. Tumors of the spleen. World J Surg 9: 468-476, 1985.

23. Kishikawa T, Numaguchi $\mathrm{Y}$, Watanabe K, Matsuura K. Angiographic diagnosis of benign and malignant splenic tumors. AJR 130: 339-344, 1978.

24. Murray BW, Lyons LC, Mancino AT, Huerta S. A report of laryngeal adenocystic carcinoma metastatic to the spleen and the role of splenectomy in the management of metastatic disease: a case report. J Med Case Rep 4: 207, 2010. 
25. Nathanson L, Hall TC, Farber S. Biological aspects of human malignant melanoma. Cancer 20: 650-655, 1967.

26. Hoar FJ, Chan SY, Stonelake PS, et al. Splenic rupture as a consequence of dual malignant pathology: a case report. J Clin Pathol 56: 709-710, 2003.

27. Hahn PF, Weissleder R, Stark DD, et al. MR imaging of focal splenic tumors. AJR 150: 823-827, 1988.

28. de Jong PA, van Ufford HM, Baarslag HJ, et al. CT and 18FFDG PET for noninvasive detection of splenic involvement in patients with malignant lymphoma. AJR Am J Roentgenol 192: 745-753, 2009.

29. Siniluoto $T$, Päivänsalo $M$, Alavaikko M. Ultrasonography of spleen and liver in staging Hodgkin's disease. Eur J Radiol 13: 181-186, 1991.

30. Munker R, Stengel A, Stäbler A, et al. Diagnostic accuracy of ultrasound and computed tomography in the staging of Hodgkin's disease. Verification by laparotomy in 100 cases. Cancer 76: 1460-1466, 1995.

\section{Correspondence}

Dr. Mehmet ÖZEN

Ankara Üniversitesi Tip Fakültesi

Cebeci Hastanesi

Hematology Bölümü ve Stem Cell Transplantasyon Birimi

4. Kat

06590 ANKARA / TURKEY

Tel: +903125957099

Fax: +903123196077

e-mail: kanbilimci@gmail.com 